\title{
RESPON PERTUMBUHAN BIBIT CENGKEH \\ (Syzgium aromaticum (L.) Merr dan Perry) KULTIVAR ZANZIBAR AKIBAT PUPUK NPK DAN PUPUK ORGANIK CAIR
}

Response on the Growth of Clove Seedling Cultivar Zanzibar as the Result of Using NPK Phonska Fertilizer Dosage and Liquid Organic Fertilizer

\author{
Yudi Yusdian, Ridwan Haris \\ Fakultas Pertanian, UNIBBA \\ yyudiyusdian@yahoo.com \\ Fakultas Pertanian, UNIBBA \\ haris0841@gmail.com
}

\begin{abstract}
The objective of this research was to study the response on the growth of clove seedling cultivar Zanzibar as the result of using NPK Phonska fertilizer dosage and liquid organic fertilizer concentration and to find out the acurate dosage of NPK Phonska and liquid organic fertilizer "Getoe". The experiment was conducted at Kampung Ciherang Desa Gunungtua Kecamatan Cijambe Kabupaten Subang, West Java. The altitude is about $600 \mathrm{~m}$ above sea level, the soil type is Ultisol (pH 5,4), the average of rainfall was 1622,10 mm/year and the type of rainfall is $C$ according to Schmidt and Ferrguson (1951). The experiment from March 2014 until June 2014. The experiment was arranged in Randomized Block Design (RBD) consisted of six treatments, i.e : A (2,5 $g$ NPK +0 cc/L of water POC Getoe), B (1,5 g NPK + 2,5 cc/L of water POC Getoe), C (2,0 g NPK + $2 \mathrm{cc} / \mathrm{L}$ of water POC Getoe), D (2,5 g NPK + 1,5 cc/L of water POC Getoe), E (3,0 g NPK + 1,0 cc/L of water $P O C$ Getoe $)$ and $F(3,5 \mathrm{~g} N \mathrm{~N}+0,5 \mathrm{cc} / \mathrm{L}$ of water POC Getoe) and replicated six times respectively. The result of this research showed that combined 2,5 $\mathrm{g}$ NPK fertilizer and 1,5 cc Getoe liquid organic fertilizer concentration gave the better effect on stem height, leaves of number, leaf area, dry weight of plant and dry weight of root the clove seedling cultivar Zanzibar.
\end{abstract}

Keywords : zanzibar, NPK and liquid organic fertilizer

\section{PENDAHULUAN}

Cengkeh (Syzgium aromaticum (L.) Merr dan Perry) merupakan tanaman rempah yang termasuk dalam komoditas dari sektor perkebunan yang mempunyai peranan cukup penting antara lain sebagai penyumbang pendapatan negara yang berasal dari cukai rokok, penyerap tenaga kerja, penyumbang pendapatan petani, sebagai sarana untuk pemerataan wilayah pembangunan dan turut serta dalam pelestarian sumber daya alam dan lingkungan. Langkah awal pengembangan cengkeh adalah pemilihan bibit yang kuat dan sehat. Bibit yang sehat dan kuat hanya bisa diperoleh dengan pemeliharaan dan kultur teknis yang baik sewaktu dipembibitan. Bibit merupakan salah satu faktor yang penting dalam menentukan hasil, sedangkan untuk memperoleh bibit yang baik diperlukan bahan yang baik di pembibitan. Pembibitan tanaman cengkeh merupakan kegiatan awal pertanaman yang sangat penting bagi keberhasilan pertumbuhan tanaman selanjutnya. Bila 
kegiatan tersebut dapat dilaksanakan dengan baik, berarti setengah tahapan pembudidayaan cengkeh sudah selesai (Trisilawati dan Demaria Tarigan, 1997).

Pupuk dapat berupa organik maupun anorganik yang diberikan ke dalam tanah dan atau melalui daun dengan maksud menambah unsur hara yang diperlukan tanaman, sehingga tanaman dapat tumbuh dan berproduksi dengan maksimal. Berdasarkan unsur hara yang diperlukan tanaman maka harus disesuaikan dengan fungsinya, terutama unsur hara makro dan mikro harus selalu tersedia, karena kekurangan salah satu unsur hara makro dan mikro akan menimbulkan gejala defisiensi pada tanaman.Adapun pupuk yang dapat diaplikasikan adalah pupuk NPK Phonska dengan pupuk organik cair (POC) Getoe dimana pupuk ini mengandung unsur hara yang dibutuhkan oleh tanaman baik unsur hara makro maupun unsur hara mikro yang juga disertai bahan-bahan organik. Di samping pemberian pupuk NPK Phonska sebagai pupuk dasar tanaman cengkeh juga memerlukan pupuk mikro untuk menunjang pertumbuhannya seperti : pupuk POC Getoe. Dengan mengkombinasikan antara NPK Phonska dengan pupuk POC Getoe, diharapkan akan memberikan pengaruh yang baik terhadap pembibitan tanaman cengkeh

Goeswono Soepardi (1983), pemupukan pada tanaman dilakukan bila persediaan hara dalam tanah tidak mencukupi kebutuhan tanaman. Oleh karena itu, pemberian pupuk dalam jumlah cukup dengan jenis yang tepat merupakan salah satu cara untuk menciptakan persediaan hara yang diperlukan tanaman.

Pupuk NPK merupakan pupuk majemuk lengkap (complete fertilizer), untuk memenuhi kebutuhan pupuk yang digunakan berbagai jenis tanaman, dalam pemakaiannya pupuk tersebut harus dipilih dengan perbandingan NPK yang sesuai dengan keperluan unsur hara yang berlaku untuk setiap jenis tanaman. Penggunaan pupuk NPK untuk tanaman cengkeh pada waktu pembibitan adalah 2,5 $\mathrm{g}$ per bibit, dimana pemberiannya dilakukan setiap tiga bulan pada umur tiga, enam dan sembilan bulan (Trisilawati dan Dameria Tarigan, 1997). Selain itu pemberian pupuk daun dapat dilakukan untuk menunjang pertumbuhan tanaman. Pupuk daun yang digunakan adalah pupuk organik cair Getoe. Pupuk organik cair Getoe merupakan pupuk cair hasil dari fermentasi bakteri pengurai alami dibuat dari bahan organik dan anorganik dengan formulasi khusus untuk pertumbuhan tanaman. Adapun kandungan unsur hara dari pupuk organik cair Getoe adalah $0,45 \% \mathrm{~N}$, 0,16 \% P2O5, 1,02 \% K2O, 0,02 \% Fe, 6,96 ppm $\mathrm{Cu}$, 15,58 ppm Zn, 0,27 ppm Co, 39,02 ppm Mn, 92,70 ppm Mg, 19,98 ppm Mo dan $0,02 \% \mathrm{Ca}$, asam amino dan protein. Pupuk organik cair Getoe berwarna kecoklatan dan mudah larut dengan air dengan aroma tidak menyengat. Anjuran penggunaan pupuk organik cair Getoe adalah $1-2 \mathrm{cc}$ per liter air untuk tanaman sayuran, pangan maupun perkebunan. 


\section{METODE PENELITIAN}

Metode penelitian yang digunakan adalah metode eksperimen dengan Rancangan Acak Kelompok (RAK), yang terdiri dari enam perlakuan dan diulang empat kali. Jumlah tanaman per plot adalah empat tanaman termasuk dua tanaman sebagai sampel, sehingga jumlah tanaman dalam penelitian ini sebanyak 96 tanaman. Sedangkan taraf perlakuan tertera pada Tabel 1 .

Tabel 1. Perlakuan Kombinasi Dosis Pupuk NPK Phonska dan POC Getoe

\begin{tabular}{cccc}
\hline \multirow{2}{*}{ No } & Notasi & \multicolumn{2}{c}{ Perlakuan Kombinasi } \\
\cline { 3 - 4 } & & NPK Phonska $(\mathrm{g})$ & POC Getoe \\
\hline 1 & $\mathrm{~A}$ & 2,5 & $0 \mathrm{cc} / \mathrm{L}$ air \\
2 & $\mathrm{~B}$ & 1,5 & $2,5 \mathrm{cc} / \mathrm{L}$ air \\
3 & $\mathrm{C}$ & 2,0 & $2,0 \mathrm{cc} / \mathrm{L}$ air \\
4 & $\mathrm{D}$ & 2,5 & $1,5 \mathrm{cc} / \mathrm{L}$ air \\
5 & $\mathrm{E}$ & 3,0 & $1,0 \mathrm{cc} / \mathrm{L}$ air \\
6 & $\mathrm{~F}$ & 3,5 & $0,5 \mathrm{cc} / \mathrm{L}$ air \\
\hline
\end{tabular}

\section{HASIL PENELITIAN}

Pengamatan yang dilakukan antara lain : pertambahan tinggi batang dan pertambahan jumlah daun yang dilakukan pada umur 4,8 dan 12 Minggu Setelah Tanam (MST), sedangkan luas daun, bobot kering tanaman dan bobot kering akar dilakukan pada akhir percobaan yaitu pada umur 12 MST.Berdasarkan hasil analisis statistik dan uraian di muka menunjukkan bahwa pemberian kombinasi pupuk NPK Phonska dan pupuk organik cair Getoe berpengaruh baik terhadap pertumbuhan bibit cengkeh kultivar Zanzibar. Pengaruh baik tesebut dapat dilihat pada peningkatan tinggi batang, jumlah daun, luas daun, bobot kering tanaman dan bobot kering akar. Perlakuan D (2,5 g NPK Phonska dan 1,5 cc/L air POC Getoe) memberikan pengaruh yang lebih baik terhadap peningkatan tinggi batang, jumlah daun, luas daun, bobot kering tanaman dan bobot kering akar (Tabel 2, Tabel 3 dan Tabel 4), pada bibit cengkeh kultivar Zanzibar. Hal ini menunjukkan bahwa kombinasi tersebut merupakan kombinasi yang optimal, di mana unsur hara makro maupun unsur hara mikro dapat diserap oleh tanaman secara maksimal, sehingga dapat mencukupi untuk memenuhi kebutuhan tanaman. Pemberian NPK Phonska dan pupuk organik cair Getoe merupakan kombinasi yang sesuai untuk memacu pertumbuhan bibit cengkeh kultivar Zanzibar. Dengan melihat kandungan pupuk tersebut seperti NPK Phonska yaitu $15 \%$ N, $15 \% \mathrm{P}_{2} \mathrm{O}_{5}$ dan $15 \% \mathrm{~K}_{2} \mathrm{O}$, sedangkan pupuk organik cair Getoe $0,45 \% \mathrm{~N}, 0,16 \% \mathrm{P}_{2} \mathrm{O}_{5}, 1,02 \% \mathrm{~K}_{2} \mathrm{O}$, 0,02\% Fe, 6,96 ppm Cu, 15,58 ppm Zn, 0,27 ppm Co, 39,02 ppm Mn, 92,70 ppm Mg, 19,98 
ppm Mo dan 0,02\% Ca, asam amino dan protei.

Tabel 2. Pengaruh Kombinasi Dosis NPK Phonska dan Konsentrasi Pupuk Organik Cair (POC) Getoe terhadap Rata-rata Pertambahan Tinggi Batang $(\mathrm{cm})$ pada Umur 4 MST, 8 dan 12 MST

\begin{tabular}{llll}
\hline \multirow{2}{*}{$\begin{array}{c}\text { Pelakuan Kombinasi Dosis NPK } \\
\text { dan POC Getoe }\end{array}$} & \multicolumn{3}{c}{ Rata-rata Pertambahan Tinggi Batang (cm) pada Umur } \\
\cline { 2 - 4 } & $4 \mathrm{MST}$ & $8 \mathrm{MST}$ & \multicolumn{1}{c}{$12 \mathrm{MST}$} \\
\hline $\mathrm{A}=2,5 \mathrm{~g}+0 \mathrm{cc} / \mathrm{L}$ air & $2,13 \mathrm{a}$ & $4,63 \mathrm{a}$ & $6,88 \mathrm{a}$ \\
$\mathrm{B}=1,5 \mathrm{~g}+2,5 \mathrm{cc} / \mathrm{L}$ air & $2,25 \mathrm{a}$ & $4,75 \mathrm{a}$ & $7,13 \mathrm{a}$ \\
$\mathrm{C}=2,0 \mathrm{~g}+2,0 \mathrm{cc} / \mathrm{L}$ air & $2,38 \mathrm{a}$ & $5,00 \mathrm{ab}$ & $7,75 \mathrm{ab}$ \\
$\mathrm{D}=2,5 \mathrm{~g}+1,5 \mathrm{cc} / \mathrm{L}$ air & $2,75 \mathrm{a}$ & $5,75 \mathrm{~b}$ & $8,13 \mathrm{~b}$ \\
$\mathrm{E}=3,0 \mathrm{~g}+1,0 \mathrm{cc} / \mathrm{L}$ air & $2,63 \mathrm{a}$ & $5,25 \mathrm{ab}$ & $7,50 \mathrm{ab}$ \\
$\mathrm{F}=3,5 \mathrm{~g}+0,5 \mathrm{cc} / \mathrm{L}$ air & $2,50 \mathrm{a}$ & $5,13 \mathrm{ab}$ & $7,63 \mathrm{ab}$ \\
\hline
\end{tabular}

Tabel 3. Pengaruh Kombinasi Dosis NPK Phonska dan Konsentrasi Pupuk Organik Cair (POC) Getoe terhadap Rata-rata Pertambahan Jumlah Daun (helai) pada Umur 4 MST, 8 dan 12 MST

\begin{tabular}{llll}
\hline Pelakuan Kombinasi Dosis & \multicolumn{3}{c}{ Rata-rata Jumlah Daun (helai) pada Umur } \\
\cline { 2 - 4 } NPK dan POC Getoe & $4 \mathrm{MST}$ & $8 \mathrm{MST}$ & \multicolumn{1}{c}{$12 \mathrm{MST}$} \\
\cline { 2 - 4 } $\mathrm{A}=2,5 \mathrm{~g}+0 \mathrm{cc} / \mathrm{L}$ air & $2,13 \mathrm{a}$ & $4,00 \mathrm{a}$ & $6,13 \mathrm{a}$ \\
$\mathrm{B}=1,5 \mathrm{~g}+2,5 \mathrm{cc} / \mathrm{L}$ air & $2,25 \mathrm{a}$ & $4,13 \mathrm{a}$ & $6,38 \mathrm{ab}$ \\
$\mathrm{C}=2,0 \mathrm{~g}+2,0 \mathrm{cc} / \mathrm{L}$ air & $2,38 \mathrm{a}$ & $4,50 \mathrm{a}$ & $7,25 \mathrm{ab}$ \\
$\mathrm{D}=2,5 \mathrm{~g}+1,5 \mathrm{cc} / \mathrm{L}$ air & $2,25 \mathrm{a}$ & $4,63 \mathrm{a}$ & $7,50 \mathrm{~b}$ \\
$\mathrm{E}=3,0 \mathrm{~g}+1,0 \mathrm{cc} / \mathrm{L}$ air & $2,00 \mathrm{a}$ & $4,25 \mathrm{a}$ & $6,75 \mathrm{ab}$ \\
$\mathrm{F}=3,5 \mathrm{~g}+0,5 \mathrm{cc} / \mathrm{L}$ air & $1,75 \mathrm{a}$ & $4,13 \mathrm{a}$ & $6,50 \mathrm{ab}$ \\
\hline
\end{tabular}

Tabel 5. Pengaruh Kombinasi Dosis NPK Phonska dan Konsentrasi Pupuk Organik Cair (POC) Getoe terhadap Rata-rata Luas Daun $\left(\mathrm{cm}^{2}\right)$, Rata-rata Bobot Kering Tanaman $(\mathrm{g})$, dan Rata-rata Bobot Kering Akar (g) pada Umur 12 MST

\begin{tabular}{cccc}
\hline $\begin{array}{c}\text { Pelakuan Kombinasi } \\
\text { Getoe }\end{array}$ & $\begin{array}{c}\text { Rata-rata Luas } \\
\text { Daun }\left(\mathrm{cm}^{2}\right) \text { pada } \\
\text { Umur 12 MST }\end{array}$ & $\begin{array}{c}\text { Rata-rata Bobot } \\
\text { Kering Tanaman }(\mathrm{g}) \\
\text { pada Umur 12 MST }\end{array}$ & $\begin{array}{c}\text { Rata-rata Bobot } \\
\text { Kering Akar }(\mathrm{g}) \text { pada } \\
\text { Umur 12 MST }\end{array}$ \\
\hline $\mathrm{A}=2,5 \mathrm{~g}+0 \mathrm{cc} / \mathrm{L}$ air & $137,56 \mathrm{a}$ & $1,36 \mathrm{a}$ & $0,43 \mathrm{a}$ \\
$\mathrm{B}=1,5 \mathrm{~g}+2,5 \mathrm{cc} / \mathrm{L}$ air & $156,08 \mathrm{ab}$ & $1,39 \mathrm{ab}$ & $0,45 \mathrm{a}$ \\
$\mathrm{C}=2,0 \mathrm{~g}+2,0 \mathrm{cc} / \mathrm{L}$ air & $157,40 \mathrm{ab}$ & $1,45 \mathrm{ab}$ & $0,50 \mathrm{ab}$ \\
$\mathrm{D}=2,5 \mathrm{~g}+1,5 \mathrm{cc} / \mathrm{L}$ air & $171,34 \mathrm{~b}$ & $1,51 \mathrm{~b}$ & $0,56 \mathrm{~b}$ \\
$\mathrm{E}=3,0 \mathrm{~g}+1,0 \mathrm{cc} / \mathrm{L}$ air & $151,61 \mathrm{ab}$ & $1,43 \mathrm{ab}$ & $0,51 \mathrm{ab}$ \\
$\mathrm{F}=3,5 \mathrm{~g}+0,5 \mathrm{cc} / \mathrm{L}$ air & $148,45 \mathrm{ab}$ & $1,41 \mathrm{ab}$ & $0,48 \mathrm{ab}$ \\
\hline
\end{tabular}


Dengan demikian pemupukan merupakan salah satu cara untuk memperbaiki kesuburan tanah sehingga tanaman cukup mendapatkan unsur hara bagi pertumbuhannya.Unsur hara tersebut berpengaruh terhadap pertumbuhan vegetatif, seperti yang dikemukakan oleh Dwidjoseputro (1986) bahwa unsur hara berperan penting dalam proses respirasi, pembentukan klorofil dan merangsang pembentukan akar.

Menurut Novizan (2002) apabila pemberian pupuk yang mengandung unsur hara makro dan mikro pada takaran dan konsentrasi yang tepat, maka karbohidrat sebagian besar diubah menjadi protein. Dengan demikian protoplasma banyak dibentuk, maka perkembangan tanaman semakin baik. Sedangkan menurut Mul Mulyadi Soetedjo (1993) dengan memberikan pupuk yang sesuai akan memberikan pengaruh yang baik terhadap pertumbuhan tanaman. Dengan tersedianya unsur hara (makro dan mikro) ini dapat dimanfaatkan oleh tanaman, maka akan terbentuk pertumbuhan yang baik seperti yang dikemukakan oleh Djoehana
Setyamidjaya (1989) bahwa unsur hara makro dan mikro dalam komposisi yang seimbang akan berperan dalam memacu pertumbuhan tanaman akar, batang dan daun. Menurut Gardner, Pearce dan Mitchell (1991) pertumbuhan dan perkembangan merupakan proses yang penting dalam kehidupan dan perkembangbiakan suatu spesies. Pertumbuhan dan perkembangan berlangsung secara terus menerus sepanjang daur hidup, tergantung pada tersedianya meristem, hasil asimilasi, hormon dan subtansi pertumbuhan lainnya serta lingkungan yang mendukung. Pertumbuhan terjadi akibat adanya pembelahan dan pembesaran sel, atau pertambahan berat kering. Sedangkan letak jaringan meristem adalah meristem ujung, lateral dan interkalar. Pertumbuhan ujung cenderung menghasilkan pertambahan panjang, pertumbuhan lateral menghasilkan pertambahan lebar. Pemanjangan batang dan daun terutama terjadi dalam meristem interkalar yang memerlukan tambahan hormon pertumbuhan dan mempunyai jumlah sel ataupun aktivitas sel yang rendah. 


\section{KESIMPULAN DAN SARAN}

\section{KESIMPULAN}

Dari pembahasan yang telah diuraikan terdahulu, maka dapat ditarik kesimpulan sebagai berikut :

1. Pemberian kombinasi pupuk NPK Phonska (15:15:15) dan pupuk organik cair Getoe berpengaruh baik terhadap pertumbuhan bibit cengkeh kultivar Zanzibar yang berbeda.

2. Kombinasi 2,5 g NPK Phonska dan 1,5 cc/L air pupuk organik cair Getoe memberikan pengaruh yang lebih baik terhadap pertambahan tinggi batang, pertambahanjumlah daun, luas daun, bobot kering tanaman dan bobot kering akar bibit cengkeh kultivar Zanzibar

\section{DAFTAR PUSTAKA}

Djohana Setyamidjaja. 1986. Pupuk dan Pemupukan. CV. Simplex. Jakarta.

Dwidjoseputro. 1986. Pengantar Fisiologi Tumbuhan. Penerbit PT. Gramedia Jakarta.

Gardner, F.P., Pearce R.B., dan R.L. Mitchell. 1991. Physiology of Crop Plants. Lowa States University Press. Amess Iowa.

Goeswono Soepardi. 1983. Sifat dan Ciri Tanah 1 dan 2. IPB Bogor.

Mul Mulyadi Soetedja. 1993. Pupuk dan Cara Pemupukan. Bina Angkasa Jakarta

\section{Ucapan Terimakasih :}

1. Kepada civitas akademika Faperta Unibba

2. Aries Kurniawan yang telah membantu dalam kegiatan penelitian ini

\section{SARAN}

Untuk memperoleh hasil penelitian yang lebih mantap dari pengaruh kombinasi NPK Phonska dan pupuk organik cair Getoe, disarankan agar dilakukan percobaan yang sejenis dengan tempat dan waktu yang berbeda. Adapun dosis/konsentrasi yang ianjurkan di pembibitan cengkeh adalah : 2,5 g NPK Phonska dan 1,5 cc/L air pupuk organik cair Getoe.

Novizan. 2002. Petunjuk Pemupukan yang Efektif. Agromedia Putaka Jakarta.

Schmidt F.H. and Ferguson. 1951. Rainfall Types Based on Wet and Dry Periods Area for Indonesia With Western New Guinea. Kementrian Perhubungan Jawatan Meteorologi dan Geofisika. Verhandeling No. 42 Jakarta.

Trisilawati dan Dameria D. Tarigan. 1997. Persemaian dan Pembibitan Cengkeh. Monograf Tanaman Cengkeh. Balai Penelitian Tanaman Rempah dan Obat. 


\section{TATA CARA PENULISAN ARTIKEL HASIL PENELITIAN ATAU STUDI PUSTAKA}

\section{SISTIMATIKA PENULISAN}

a. Bagianawal : judul, namapenulis, abstraksi.

b. Bagianutama : berisipendahuluan, Kajian literature danpengembanganhipotesis (jikaada), cara/metodepenelitian, hasilpenelitiandanpembahasan, dankesimpulandan saran(jika ada).

c. Bagianakhir : ucapanterimakasih (jikaada), keterangansimbol (jikaada), dandaftarpustaka.

\section{JUDUL DAN NAMA PENULIS}

a. Judul dicetak dengan huruf besar/kapital, dicetak tebal (bold) dengan jenis huruf Times New Romanfont 12, spasi tunggal dengan jumlah kata maksimum 15.

b. Nama penulis ditulis di bawah judul tanpa gelar, tidak boleh disingkat, diawali dengan huruf kapital, tanpa diawali dengan kata "oleh", urutan penulis adalah penulis pertama diikuti oleh penulis kedua, ketiga dan seterusnya.

c. Nama perguruan tinggi dan alamat surel (email) semua penulis ditulis di bawah nama penulis dengan huruf Times New Romanfont 10.

d. Arttikel yang berasal dari tesis harus mencantumkan pembimbing sebagai penulis ke dua
ABSTRACT
a. Abstract ditulis dalam bahasa Inggris, berisi tentang inti permasalahan/latar belakang penelitian, cara penelitian/pemecahan masalah, dan hasil yang diperoleh. Kata abstract dicetak tebal (bold).
b. Jumlah kata dalam abstract tidak lebih dari 250 kata dan diketik 1 spasi.
c. Jenis hurufabstract adalahTimes New Romanfont 11, disajikan dengan rata kiri dan rata kanan, disajikandalam satu paragraph, dan ditulis tanpa menjorok (indent) pada awal kalimat.
d. Abstract dilengkapi denganKeywords yang terdiri atas 3-5 kata yang menjadi inti dari uraian abstraksi.Kata Keywords dicetak tebal (bold).

\section{ATURAN UMUM PENULISAN NASKAH}

a. Setiap sub judul ditulis dengan huruf Times New Romanfont 11 dan dicetak tebal (bold).

b. Alinea baru ditulis menjorok dengan indent-first line $0,75 \mathrm{~cm}$, antar alinea tidak diberi spasi.

c. Kata asing ditulis dengan huruf miring.

d. Semua bilangan ditulis dengan angka, kecuali pada awal kalimat dan bilangan bulat yang kurang dari sepuluh harus dieja.

e. Tabel dan gambar harus diberi keterangan yang jelas, dan diberi nomor urut.

\section{REFERENSI}

Penulisan pustaka menggunakan sistem Harvard Referencing Standard. Semua yang tertera dalam daftar pustaka harus dirujuk di dalam naskah. Kemutakhiran referensi sangat diutamakan.

\section{A. Buku}

[1] Penulis 1, Penulis 2 dst. (Namabelakang, namadepandisingkat). Tahunpublikasi. JudulBukucetak miring. Edisi, Penerbit. TempatPublikasi.

\section{B. ArtikelJurnal}

[2] Penulis 1, Penulis 2 danseterusnya, (Namabelakang, namadepandisingkat). Tahunpublikasi.

Judulartikel.NamaJurnalCetak Miring. Vol. Nomor. RentangHalaman.

\section{Prosiding Seminar/Konferensi}

[3] Penulis 1, Penulis 2 dst, (Namabelakang, namadepandisingkat). Tahunpublikasi. Judulartikel.NamaKonferensi. Tanggal, BulandanTahun, Kota, Negara. Halaman.

\section{TesisatauDisertasi}

[4] Penulis (Namabelakang, namadepandisingkat). Tahunpublikasi. Judul.Skripsi, Tesis, atauDisertasi.Universitas.

\section{E. SumberRujukandariWebsite}

[5]Penulis. Tahun. Judul.Alamat Uniform Resources Locator (URL). Tanggal Diakses.

\section{PASPALUM terbit 2 kali dalam setahun yaitu pada bulan Maret dan bulan September}

